2014

\title{
Poetry, Mercy, and the Phenomenology of Justice
}

Benjamin L. Berger

Osgoode Hall Law School of York University, bberger@osgoode.yorku.ca

Follow this and additional works at: http:// digitalcommons.osgoode.yorku.ca/olsrps

\section{Recommended Citation}

Berger, Benjamin L., "Poetry, Mercy, and the Phenomenology of Justice" (2014). Osgoode Legal Studies Research Paper Series. 32. http://digitalcommons.osgoode.yorku.ca/olsrps/32 


\section{OSGOODE HALL LAW SCHOOL LEGAL STUDIES RESEARCH PAPER SERIES}

\section{Research Paper No. 34}

Vol. 10/ Issue. 09/ (2014)

\section{Poetry, Mercy, and the Phenomenology of Justice}

In Ehud Ben Zvi, Claudia V. Camp, David M. Gunn and Aaron W. Hughes, eds., Poets, Prophets, and Texts in Play: Studies in Biblical Poetry and Prophecy in Honour of Francis Landy (London: T \& T Clark, forthcoming 2014).

Benjamin L. Berger

\section{Editors:}

Editor-in-Chief: Carys J. Craig (Associate Dean of Research \& Institutional Relations and Associate Professor, Osgoode Hall Law School, York University, Toronto)

Production Editor: James Singh (Osgoode Hall Law School, York University, Toronto) 
Osgoode Legal Studies Research Paper No. 34

Vol. 10/ Issue. 09/ (2014)

\title{
Poetry, Mercy, and the Phenomenology of Justice
}

In Ehud Ben Zvi, Claudia V. Camp, David M. Gunn and Aaron W. Hughes, eds., Poets, Prophets, and Texts in Play: Studies in Biblical Poetry and Prophecy in Honour of Francis Landy

(London: T \& T Clark, forthcoming 2014).

Benjamin L. Berger

\begin{abstract}
:
What would a phenomenology of justice look like and what role would mercy play in that account? The unruly experiences and lives of the individuals and communities wrapped up in the dramas of justice are paradoxically distant from legal and philosophical reasoning, laundered by rules of evidence for the instrumental exigencies of the former, and frequently effaced by the disciplinary conventions of the latter. One casualty of these habits of reflection is our understanding of the role of mercy in the experience of justice. Wanting to recapture space to imagine the role of mercy in justice, this paper makes an exploratory turn to a world consumed with representing the messy experience of justice and still thick with the language of mercy - to the poetic and narrative world created in the Book of Jonah. Drawing inspiration from a close reading of this mythic tale, I argue that mercy is an essential feature of the phenomenological architecture of justice, requiring us, as it does, to connect abstract judgment with the complexities and exigencies of our concrete conditions. Though distant from contemporary legal and political theory, I argue that mercy in fact remains an uncanny aspect of our experience of justice and so demands a political and legal scholarship that spends as much time reflecting on the sources and nature of mercy as a political virtue, as it does on the demands of reason and the dictates of law alone.
\end{abstract}

\section{Keywords:}

Phenomenology; Justice; Mercy; Law; Book of Jonah; Literary Interpretation

\section{Author(s):}

Benjamin L. Berger

Associate Professor

Osgoode Hall Law School

York University, Toronto

E: bberger@osgoode.yorku.ca 


\title{
Poetry, Mercy, and the Phenomenology of Justice
}

\author{
Benjamin L. Berger*
}

What would a phenomenology of justice look like? Legal and political philosophy are thick with theories of justice. In the articulation and defence of those theories, thought conventionally proceeds from ideal principle or $a$ priori commitment to a claim about what justice ought to look like or what principles should guide us in pursuit of the just. The experience of justice-of wrong and pain, of judgment and forgiveness, of punishment and redemption-is notably absent from scholarly reflection about the nature of justice. This is, in some measure, an artefact of the nature of the disciplines and their sources. Neither case law, statute, nor treatise gives priority to the messiness of everyday life. Indeed, the suppression of experience is a feature of law and much political philosophy, both of which thrive on the muting of certain voices in favor of authoritative others and on the sorting and rendering of "the facts" to serve analytic ends. The unruly experiences and lives of the individuals and communities wrapped up in the dramas of justice are paradoxically distant from legal and philosophical reasoning, laundered by rules of evidence (and the tyranny of relevance) for the instrumental exigencies of the former, and frequently effaced by the disciplinary conventions of the latter. There is much truth in Bruno Latour's felicitous image of attempting to access knowledge of life through the language of law: that doing so is "like trying to fax a pizza". ${ }^{1}$

Might it be that certain features of the experience of justice drop out of view with this troubling inaccessibility of life itself? Of particular interest in this chapter is the contemporary place of mercy in our understanding of justice. To say that we do not live in merciful times could be to make two quite different observations, though they might turn out to be related. One would be the claim that we are experiencing a time of increased harshness in the law, a period characterized by an excess of punitiveness and a scarcity of compassion. Such a claim is no doubt defensible in some political and legal contexts, though it tends to wither in historical perspective. The more

\footnotetext{
* Associate Professor, Osgoode Hall Law School, York University. Thank you to Hannah Askew, John Borrows, Lisa Kerr, and James Stribopoulos for their generous engagement with earlier drafts of this piece. Many thanks also to Geneviève Murray (JD, Osgoode/NYU) for her excellent research assistance in the preparation of this chapter. The author gratefully acknowledges the financial support of the Social Sciences and Humanities Research Council.

${ }^{1}$ Bruno Latour, The Making of Law: An Ethnography of the Conseil d'Etat (Cambridge, UK: Polity Press, 2010), 268.
} 
reliable claim is that we live in times in which talk of mercy does not circulate freely in legal and political reflection, times in which mercy does not present itself prominently as a political or legal virtue. That observation seems harder to contest. Indeed, language of mercy - once more central to political rhetoric about the interaction of law and justice, but more on this later would seem oddly out of place in contemporary institutions of governance. Language of mercy is not absent from the social world, but its appearance in political or legal registers seems like a category error, somehow anachronistic, perhaps even a little embarrassing. Speaking of mercy seems incongruous with the rhetorical and analytical conventions of the modern secular rule of law. But the force of these conventions nevertheless leaves the organizing question in this chapter untouched: what role, if any, does mercy play in the experience of justice and what might this suggest about the nature of justice itself?

This is a fundamentally phenomenological question, one that seeks to ground reflection in the experience of lived encounter. The great hermeneutic phenomenologist Wilhelm Dilthey claimed that "life is the basic element or fact which must form the starting point for philosophy"; that life is that "behind which we cannot go." 2 As a legal theorist, given the constraints of traditional sources and texts, where can one turn for access to "life"? Some might turn to the empirical, some to ethnography, others still to history. Yet this is also when narrative, story, and poetry offer themselves. In these creative forms we find a capacity to unsettle ideas, to aggravate convention, and trouble settled wisdom. And so, despite my years in the wilderness of legal scholarship, this exploratory return to poetry and prophecy is very much influenced by the guiding ethos of the work of Francis Landy: that life can be found in the poetry and stories that communities hold precious over time; that there is an existential wisdom to be found in poetry and through attention to the fruits of imagination.

Wanting to recapture space to imagine the role of mercy in justice, I turn to a world consumed with representing the messy experience of justice and still thick with the language of mercy, the world created in the Book of Jonah. After listening carefully to the narrative and metaphor of the story of Jonah, I will turn back to consider what lessons it might offer about the place of mercy in the architecture of justice and what this might suggest for contemporary legal and political thought.

\footnotetext{
${ }^{2}$ Wilhelm Dilthey, Gessammelte Schriften (vol. VII; Stuttgart: B.G. Teubner, 1959), 359.

Translated and cited in Richard E. Palmer, Hermeneutics: Interpretation Theory in

Schleiermacher, Dilthey, Heidegger, and Gadamer (Evanston: Northwestern University Press, 1969), 120.
} 


\section{Justice, Mercy, and the Book of Jonah}

The Book of Jonah offers itself as a parable. ${ }^{3}$ It begins in the familiar idiom of the prophetic writings - "the word of the Lord came to Jonah son of Amittai" 4 - but this form is conjured only to be immediately disrupted. Having heard God's judgment against the city of Nineveh and received his instruction to "Go at once to Nineveh" to communicate that judgment, Jonah flees, seeking to escape his task. The trope of the reluctant prophet is common enough to the Hebrew Bible, but, as with much in this strange story, the Book of Jonah plays with and magnifies the form, alerting the reader that she is in a different kind of narrative space, a kind of parody of prophecy that is stamped with didactic intentionality. ${ }^{5}$ Jonah is also a strangely private prophet, with narrative taking precedence over prophecy in the Book. Apart from his brief exchange with the sailors on the ship to which he flees from God, an exchange that culminates with him declaring his own guilt and sentence (to be heaved overboard in order to calm the sea), Jonah pronounces only one short phrase capable of being heard by an audience in his narrative world: his perfunctory statement, just $1 / 3$ of the way into Nineveh, that "Forty days more, and Nineveh shall be overthrown!" (Jonah 3:4) The imagined audience of the story is the reader, who travels alongside an omniscient narrator, zooming from sea to city, into the belly of a fish and

\footnotetext{
${ }^{3}$ I am mindful that the question of the technical genre to which the Book of Jonah belongs - be it satire, allegory, folktale, midrash, parody, etc. - is a contentious one in the literature. See, for example, Thomas M. Bolin, Freedom Beyond Forgiveness: The Book of Jonah Re-Examined (Sheffield: Sheffield Acadmic Press, 1997), 46ff. Not interested (or equipped) to enter into this debate, I am describing the story as "parable" in a more casual sense, emphasizing my reading of the Book as a short story intended to communicate a lesson.

${ }^{4}$ All quotations from the Book of Jonah are based on the Jewish Publication Society translation of the Tanakh (1985), checked against the author's reading of the Hebrew text and except where otherwise indicated.

${ }^{5}$ On the basis of the atypical features of the book, Ben Zvi characterizes the Book of Jonah as a "meta-prophetic" book, in which "the literary genre and the image of past prophets are manipulated... for rhetorical purposes." See Ehud Ben Zvi, Signs of Jonah: Reading and Rereading in Ancient Yehud (London and New York: Sheffield Academic Press, 2003), 82. On the Book of Jonah as parody, see William W. Hallo, "Jonah and the Uses of Parody," in Thus Says the Lard: Essays on the Former and Latter Prophets in Honor of Robert R. Wilson (eds. Ahn and Cook; New York and London: T \& T Clark, 2009), 285-291. Hallo explains that the book "mocks the conventions of classical prophecy, from the divine call at the outset, through the personal involvement, and even misadventures, of the prophet, to the abrupt and surprising ending" (290). For an account of the various intertextual allusions and references in the Book of Jonah, see Hyun Chul Paul Kim, "Jonah Read Intertextually," Journal of Biblical Literature 126.3 (2007): 497-528.
} 
the interior life of Jonah. ${ }^{6}$ The reader is the narrator's audience, not the prophet's.

All of this contributes to the strong narrative hand characteristic of parable and folk tale, a parabolic sense that is deepened by the notable brevity of the story and, of course, the appearance in the story of fantastic elements - a giant fish that rescues Jonah from the sea, and a magical plant, whose creation and destruction plays a pivotal role in the didactic climax of the story. The central dramatic tension is introduced in the story swiftly and clearly, avoiding any kind of distraction and dispensing with narrative foreplay. The word of God comes to Jonah, instructs him, but he chooses to flee. The reader is, thus, immediately confronted with the problem that frames the story and anchors the message of the book: why did Jonah flee?

If we are invited to encounter the Book of Jonah as a parable, what is it a parable about? The reading that I wish to explore in this piece is that the Book of Jonah is, at its heart, a parable about the nature of justice. ${ }^{7}$ More particularly, the narrator of the Book is interested in communicating a message about the relationship between judgment and mercy, the human temptations of the former and the need and virtue of the latter. This short story is thick with moments of judgment, of punishment and forbearance, and invocation of that complicated word hesed -"compassion" or "mercy". Read in one way, the cumulative message of these episodes of judgment and justice is to underscore and valorize God's mercy and compassion in response to remorse. God saves Jonah from the sea when he calls out in prayer, he saves the people of Nineveh when their King leads them in the collective expression of repentance. My reading is somewhat different. Close attention to the structure of the culminating metaphor of the story points not to a message about God's mercy, but about the human perils of finding comfort in the life-flattening simplicity of judgment.

Before focussing in on this pivotal metaphor with which the Book of Jonah concludes, it is worth mapping the narrative shape of the story of Jonah with this focus on judgment and mercy in mind, drawing out certain key features of the tale. The story begins, of course, with God announcing his

\footnotetext{
${ }^{6}$ On the narrative and rhetorical structure of the Book of Jonah, see Benjamin L. Berger, "Picturing the Prophet: Focalization in the Book of Jonah," Studies in Religion 29. 1 (2000): 5568; Kenneth M. Craig, Jr., A Poetics of Jonah: Art in the Service of Ideology (Columbia, SC: University of South Carolina Press, 1993).

${ }^{7}$ For a helpful survey of various historical and modern interpretations of, and interpretive debates about, the Book of Jonah, see Bolin, Freedom Beyond Forgiveness. See also T. Anthony Perry, The Honeymoon is Over: Jonah's Argument with God (Peabody, MA: Hendrickson Publishers, 2006). For an insightful analysis of the readings available to the ancient readers of the Book of Jonah, see Ben Zvi, Signs of Jonah.
} 
judgment of Nineveh to Jonah, a judgment that arises because "their wickedness has come before Me" (Jonah 1:1). The Book's call and response rhythm of judgment and reaction, mercy and reaction, begins immediately, with Jonah's flight to Tarshish. Why does he flee? Does he disagree with the judgment? Does he think it unfair? Does he recoil at the looming loss of life? The reader simply doesn't know at this point. And with this, the initial narrative line concerned with the judgment and treatment of Nineveh is suspended, and focus turns to Jonah's voyage to Tarshish by sea.

A storm hits the ship, endangering the non-Hebrew crew who call out in fear to their various gods. Flinging cargo into the sea to lighten the ship in the hopes of saving themselves, they discover Jonah sleeping in the hold. Roused by the sailors and called upon to assist, Jonah remains silent. The sailors decide to take action and cast lots to determine who is responsible for the storm. The lot falls on Jonah. This is the second moment of judgment in the Book. Jonah tells them who he is and that he worships "the Lord, the God of Heaven, who made both sea and land" (Jonah 1:9). The men are terrified to learn that his guilt arises from fleeing the service of his God, asking what they can do to save themselves. Jonah admits his responsibility and pronounces his own sentence: they should throw him overboard.

It is here that the reader finds the first expression of mercy, not from God but from these foreign sailors who worship other gods. A sound judgment firmly in hand and a sensible punishment pronounced, they nevertheless initially decline to throw Jonah overboard, futilely rowing instead for the shore. When this fails they resign themselves to the judgment and punishment, expressing concern, however, that the judgment is accurate. "Do not hold us guilty of killing an innocent person," they cry out, before heaving Jonah overboard. When the sea calms, the judgment of the lots is, in a sense, confirmed on appeal: Jonah was guilty and this punishment is correct.

In a remarkable scene change, the narrative focus moves to Jonah praying to God, cradled inside the belly of a huge fish that God sent to save Jonah. For three days and nights he lives in the belly and, in our most sustained exposure to Jonah's internal life, the reader is told what Jonah says when he prays to God. In his song, Jonah describes in poetic detail the experience of his punishment, of God (note, not the sailors) casting him into the sea, the darkness and estrangement from God that Jonah experienced as the waters flooded over him, and his moment of realization that he will not see the Temple again. Jonah sings that he prayed to God and God responded, saving his life. And his conclusion? Jonah affirms that he will obey God, will sacrifice to Him, and proclaims that "Deliverance is the Lord's!" (Jonah 2:10) 
But he also states a lesson from his experience, a lesson whose meaning is elusive and variously interpreted: "They who cling to empty folly / forsake their own welfare" (Jonah 2:9). Sasson, who notes that this "strophe" stands out from the rest of the prayer, translates Jonah's aphorism differently: "They who hold to empty faiths, / give up their hope for mercy". ${ }^{8}$ The pivotal words are havlei-sav and hasdam, a form of the word hesed. The first carries the sense of vanity or illusion, of extreme folly. The second - holding the senses of mercy and compassion - will reappear as the story unfolds; here it carries the third person personal suffix, suggesting that what is at stake is the loss of their mercy. This is a curious lesson whose meaning is unclear at this stage in the story, but its emphasis is, on my reading, significant.

After the fish vomits Jonah onto the beach, the larger narrative arc resumes, or more accurately restarts, with Jonah's mission to Nineveh redux. God refreshes his instruction to go to Nineveh and proclaim His judgment. This time Jonah complies and when he is $1 / 3$ of the way into the city, he laconically (are we invited to think he does so reluctantly?) prophesies Nineveh's demise. The people of Nineveh respond admirably. They believe God. They immediately begin to atone, with the King declaring a period of repentance, admitting the existence of evil ways and injustices in Nineveh and calling on the residents of the city to "turn back" from that wickedness in the hope that God may, Himself "turn" - "turn and relent" and "turn back from His wrath" (Jonah 3:9). And God does. The reader is told that "God saw what they did, how they were turning back from their evil ways" and that he therefore "renounced the punishment He had planned to bring upon them" (Jonah 3:10).

It is at this point that the dramatic tension generated in the first verses of the book shows itself again, calling now for resolution. Though confirmed in his judgment of the city by the King's own admissions, God has relented from the punishment that $\mathrm{He}$ had in store for Nineveh (the wholesale destruction of the city, we are left to presume, given God's pattern of prior bad acts)..$^{9}$ This is our third act of mercy in the Book of Jonah - the sailors' mercy extended to Jonah, God's mercy extended to Jonah, and now this. Yet the reader learns that Jonah is upset by this turn of events. He is "grieved" by God's failure to punish and prays to God, providing the answer

\footnotetext{
${ }^{8}$ Jack M. Sasson, Jonah: A New Translation with Introduction, Commentary, and Interpretation (New York and London: Doubleday, 1990), 160.

${ }^{9}$ Indeed, historical Nineveh was destroyed, a fact that haunts the interpretation of the story. In particular, Ben Zvi's volume on the Book of Jonah explores the way in which this historical fact might have inflected an ancient reader's interpretation of the Book (Ben Zvi, Signs of Jonah). In this readerly world, did the common knowledge that God would eventually destroy Nineveh give a darkly ironic coloring to God's apparently rhetorical question with which the book ends?
} 
to the reader's earlier question: why did he flee? "That is why I fled before hand to Tarshish," he explains, "For I know that You are a compassionate and gracious God, slow to anger, abounding in kindness (hesed), renouncing punishment" (Jonah 4:2). ${ }^{10}$ This is the key dramatic turn in the narrative. Jonah did not flee because he recoiled from the death of hundreds of thousands in Nineveh or because he thought it unfair. Instead, compassion and mercy (hesed) are the complaint; Jonah fled because he feared that he could not rely on God to carry out His judgment. Introducing the first half of a parallelism that structures the defining metaphor of the story, Jonah prays to God to kill him, "for I would rather die than live" (Jonah 4:3), and God responds by asking "are you that deeply grieved?" (Jonah 4:4)

In his dismay, Jonah leaves the city and, building a shelter for shade, watches the city. (What is he watching for?) God now takes steps to teach Jonah a lesson. He causes a plant (qiqayon, often translated as "gourd") to grow, providing shade and comfort to Jonah, who is very pleased by the gourd, despite apparently already having shade from the booth that he built. But just as Jonah becomes attached to this plant, God sends a worm to attack the plant, killing it as the sun rises. The east wind blows and the sun beats down on Jonah's head, making him faint and adding to his despair. In a tight parallelism with his reaction to God sparing Nineveh, the narrator reports that Jonah calls out for death, saying "I would rather die than live" (Jonah 4:8), and God asking "are you so deeply grieved about the gourd?" When Jonah confirms, in his final words in the book, that yes, he is so deeply grieved that he wishes to die, God chastises him for caring so much about the gourd, which he had no role in creating, and which sped through existence and demise, and yet being insensitive to the fate of the Ninevites. "[S]hould not I care about Nineveh," God asks Jonah, "that great city, in which there are more than a hundred and twenty thousand persons who do not yet know their right hand from their left, and many beasts as well!" (Jonah 4:11)

It is this experience of the plant that is meant to teach Jonah a lesson and to afford the moral of this parable. The analogy that God draws between the plant and the lives of the people in Nineveh - specifically, those within the city who would be morally innocent - invites a certain conventional interpretation. That reading of the story takes the message as being God's justice as expressed in his regard for the lives of the innocent, and Jonah's failure as inhering in a kind of narrowness and selfishness, one that comes out in his delight at his own comfort but occludes his regard for justice. That interpretation, which turns on the parallel between the plant and the

\footnotetext{
${ }^{10}$ This is, of course, a radically incomplete description of the character of the God of the Hebrew Bible.
} 
innocent in Nineveh, is natural enough; after all, God invites it with his own words.

Yet there are problems with this reading. First, it makes God seem foolish. He was presumably always aware that there were large numbers of innocents in Nineveh and yet was, at the start of the story, willing to destroy the city in light of the wickedness of some. Second, and related, it reads the repentance of the Ninevites out of the narrative; though the story suggests in 3:10 that God stayed his executing hand because the people of Nineveh "turn[ed] back from their evil ways", taking God's analogy at face value says, instead, that God spared Nineveh for the sake of the innocent, not the actions of the guilty. Third, this reading orphans the entire episode on the ship and in the belly of the fish. Why was the narrative detail around this experience necessary? If one holds to the focus on godly compassion, this episode recedes to mere narrative device, a way of getting a reluctant prophet to Nineveh. Indeed, and crucially, on this interpretation Jonah's flight and his explanation that he, in effect, feared God's mercy remains puzzling.

But this more obvious interpretation leans, I suggest, on a flawed reading of the metaphor constructed at the end of the book. Revisiting the structure of that metaphor opens up a different message, one, I suggest that makes Jonah a much more psychologically subtle and interesting parable, one with deep contemporary political relevance.

Structurally, the parallel constructed at the end of the Book of Jonah is not drawn between the innocent people in Nineveh and the plant; it is between the original judgment against Nineveh and the plant. As readers, we are given two virtually identical sets of reactions from Jonah and responses from God - Jonah expresses his dismay by saying that he would rather die than live, and God responds by asking if he is really that deeply grieved. Both are reactions to a loss of something. The second episode is clear enough: Jonah is happy about this magically appearing plant, the plant dies, and he bemoans its loss, which leaves him exposed to the "sultry east wind" and the sun beating down on his head. God is specific in his questions: "are you so deeply grieved about the plant?" Jonah confirms the object of his grief: "yes... so deeply that I want to die."

What, then, is the loss that Jonah mourned after Nineveh is saved? If one follows the structural parallel, the loss is the "loss" of the punishment. Focussing on the comparison that God draws between the plant and the innocent of Nineveh abandons the poetic structure, thereby obscuring a key avenue of interpretation. The narrative sets up a metaphor in which the judgment against Nineveh is like the plant. How might this be so? What message might be contained in this equivalence? 
Jonah found comfort in the shelter provided by the plant that God suddenly generated; we are told that the plant provided shade for his head and rescued him from discomfort. The source of discomfort here is the lived conditions that Jonah faces sitting on the outskirts of Nineveh, the harsh reality of the wind and a punishing sun. He swiftly attaches to this plant, but it turns out that the plant was temporary, fleeting, and vulnerable. He mourns the loss of this source of shelter, one that wasn't of his creation, that he didn't really need (as he had built his own structure to offer him shade), and that "came into being overnight and perished overnight."

The plant-judgment metaphor invites the reader to view Jonah's attachment to God's judgment in similar terms. Jonah finds comfort in the certainty of judgment. Just as the plant would offer shelter from certain lived realities, so too did God's judgment. It cast a shadow over the complexity of life in Nineveh, one in which wickedness sits alongside virtue, blame meets repentance, and guilt and innocence are perilously hard to disentangle. It is easier and more comfortable, the metaphor suggests, to sit in the shade of clear and certain judgment, though this would hide from one's eyes, as it did for Jonah, the Ninevites' capacity for insight and repentance, as well as the injustices that would be done in the name of harsh and sure punishment. God spares Nineveh when his initial response to their wickedness is combined with a fuller experience of their humanity, one that reveals an internal life that is not adequately addressed by the categories of guilt and punishment. As Scholem explains, "Jonah takes the standpoint of the law, and from this side he is indeed right; God takes that of justice". ${ }^{11}$ When, in the final phrases of the book, God points to the transience of the plant and the existence of those - human and beast - that could not be held to blame, $\mathrm{He}$ is showing Jonah the folly and potential injustice of holding fast to abstract judgment at the expense of regard for the complexity of life.

On this interpretation, which arises from taking the metaphor of judgment/plant seriously, the earlier episode on the ship and Jonah's prayer inside the fish assume a central place in the message of the parable as a whole. Having felt and heard God's reproach for his attachment to the comfort of the categorical certainties of judgment, one can imagine Jonah's mind turning back to the experience of his own judgment, punishment, and rescue at sea. On the ship to Tarshish, Jonah was rightly judged responsible for the storm that threatened the ship and the lives of the sailors. Although Jonah had, in fact, confirmed his own guilt, even pronouncing his sentence, the sailors initially demurred, the first in the story to hesitate in the face of

\footnotetext{
${ }^{11}$ Gershom Scholem, "On Jonah and the Concept of Justice," Critical Inquiry 25.2 (1999): 353-61, 357. Scholem similarly reads the Book of Jonah as "a lesson about the order of the just" (354).
} 
the dangers of judgment. In his song from the belly of the fish that God sent to rescue him, Jonah describes his experience as he faced his due punishment, literally sinking into despair, drowning with regret and sadness, realizing the loss that he had brought on himself. He experiences a change, one provoked by the experience of mercy in the face of judgment. In their actions, the Ninevites manifested an experience of justice as containing within it the possibility for mercy. One can imagine Jonah, sitting on the earth outside Nineveh, recalling his own reformation in reaction to this experience of justice as generated from the mixing of raw judgment and mercy. ${ }^{12}$ In this, Jonah's song at the heart of the book offers a phenomenology of justice, one that God forces him to recall when he clings to the simple judgment, and hopes for the punishment, of Nineveh.

And then there is that strange aphorism that appears suddenly at the climax of Jonah's prayer from the belly of the fish: "They who cling to great vanity/folly (havlei-sav) forsake their own mercy (hasdam)." This phrase, which sits at the very heart of the Book - the $25^{\text {th }}$ of 48 verses - has always troubled translators. The ambiguity of the key words, hevel and hesed, is challenging; so too is the third person personal participle that modifies hesed (surely those who hold to false vanities [illusions / empty appearances] forsake God's compassion, not their own mercy?). Yet reading of the Book of Jonah given in this chapter, one in which the analogy between the judgment of Nineveh and the plant have poetic pride of place, offers an interpretation of this aphorism faithful to the central themes and preoccupations of the book: to commit to abstract judgment alone is folly; and doing so estranges one from the virtue of mercy, with its unsettling but vital demand to connect one's sense of justice with the perplexities of lived experience. ${ }^{13}$

There is a certain comfort to be found in judgment. It opens a reassuring moral chasm between the judge and the judged, sorting a confusing world neatly into right and wrong. In this way, clear and certain judgment makes the world more legible. This is its seductiveness, its considerable appeal; and this is the psychological sophistication of the Book of Jonah. A world in which judgments can be confidently made and relied upon seems sensible, orderly, and safely uncomplicated. It is a world in which action, desert, and consequence march in predictable sequence. That

\footnotetext{
12 "This, and nothing else," Scholem argues in his interpretation of the Book of Jonah, "is the meaning of justice in the deepest sense: that judgment $i$ allowed, but the execution of it remains something entirely different" (ibid., 357, emphasis in original.)

${ }^{13}$ Nussbaum similarly views regard for complexity as at the heart of the exercise of mercy in judgment; whereas I look to biblical narrative and poetry in this chapter, Nussbaum, in her fascinating piece, offers the novel as a kind of literary paradigm for merciful engagement. See Martha C. Nussbaum, "Equity and Mercy," Philosophy \& Public Affairs 22.2 (1993): 83-125.
} 
is the world in which Jonah wants to take refuge, just as he took refuge under the plant. It is the world that he seeks to preserve by fleeing, knowing that, once faced with the Ninevites' lived realities and capacity for change, mercy might complicate matters. Yet, however comforting, this world of abstract judgment is no more committed to the real than the evanescent plant. Justice for Nineveh comes when God takes account not only of the Ninevites' wickedness, but of the moral complexity of their situation and their capacity for insight and change. On this reading, the parable of the Book of Jonah teaches what Jonah learned in the belly of the fish: that, phenomenologically, justice is not found in condemnation and punishment alone, but in the confluence of judgment and mercy.

\section{The Uncanniness of Mercy in Contemporary Political Justice}

A central ambition of the modern liberal rule of law is to subject matters of justice to the claims and demands of reason. Beating at the heart of the contemporary commitment to the rule of law is the belief that it reflects "the internalization of reason itself as a regulative ideal within the political order."14 This ideal has yielded substantial goods, those associated with modern forms of governance and law. Predictability, certainty, and transparency are all aspects of justice emphasized by this account, and are among the cardinal virtues of the modern constitutional rule of law. Within this contemporary culture of law's rule, certain personal and political virtues are exalted as the building blocks of justice: reason, fairness, and truth are the constituent elements of just law and governance. And so, when one turns to the scholarship offering theoretical reflection on the nature of justice, there is extensive discussion of the character and claims of legal reason and the demands of fairness (in the hands of some, justice is fairness) in a liberally defensible approach to justice. ${ }^{15}$ Yet, in this literature, one is hard pressed to find substantial reflection on the role of mercy as a political or legal virtue. ${ }^{16}$ Indeed, talk of mercy, with its affective and discretionary

\footnotetext{
${ }^{14}$ Paul W. Kahn, "Comparative Constitutionalism in a New Key," Michigan Law Review 101(2003): 2677, 2698.

${ }^{15}$ John Rawls, Justice as Fairness: A Restatement (Cambridge, MA: Belknap Press, 2001).

${ }^{16}$ Notable exceptions include Nussbaum, "Equity and Mercy"; N. E. Simmonds, "Judgment and Mercy," Oxford Journal of Legal Studies 13.1 (1993): 52-68. Other literature that takes up issues of mercy tends to focus more specifically on the U.S. death penalty and questions of clemency. See, e.g., P.E. Digeser, "Justice, Forgiveness, Mercy, and Forgetting: The Complex Meaning of Executive Pardoning," Capital University Law Review 31(2003): 161; Austin Sarat, Mercy on Trial: What it Means to Stop an Execution (Princeton: Princeton University Press, 2005); Austin
} 
connotations, seems positively out of place in liberal political and legal thought. To be sure, the sensibility that one finds at the heart of the parable of Jonah - that judgment, mercy, and justice are locked in an essential and immutable conversation - is foreign to this realm of contemporary thought about the nature of political and legal justice.

This absence is even more notable in the realm of law; that is, in the realm of practical judgments about justice in concrete cases. The language of justice spoken in the courts - indeed, the essential grammar of constitutional and criminal justice - is dominated by "balancing" and "proportionality," the doctrinal expressions of the ambition to have reason rule justice. ${ }^{17}$ Reliability and truth feature prominently; due process is a veritable fetish. And so when one focuses attention on the criminal justice system and the act of punishment, the most violent corner of law, one finds that concepts of proportionality, desert, and culpability reign as the constituent elements of justice. It would be surprising - the reflection of a kind of category error or role transgression - to hear a contemporary judge overtly reasoning with the concept and the demands of mercy. All of this is an artefact of the way that justice is imagined in the liberal rule of law, a world in which the domains of law and justice are coextensive.

Yet this has not always been so. For a substantial period of legal and political history, the architecture of justice was differently imagined. In the $16^{\text {th }}$ and $17^{\text {th }}$ centuries, the institutions of law sat alongside, and in dialogue with, institutions of "equity." When the formal reason of the legal rule proved unjust, one could literally cross Westminster Hall from the courts of common law to the Chancery, where, sitting in the name of the King, the Chancellor would dispense the higher justice of equity. In 1616, sitting in Star Chamber, an equitable court with jurisdiction over crime, ${ }^{18}$ King James expressed the wisdom of the time: "There is no Kingdome but hat a Court of Equitie."19 This was not an empirical claim, it was an expression of the prevailing political imaginary, one in which the central task of government was to dispense justice and law alone was not sufficient to that task. In fact, King James declared that Chancery "exceeds other Courts, mixing Mercy with

Sarat and Nasser Hussain, eds, Forgiveness, Mercy, and Clemency (Stanford: Stanford University Press, 2007).

${ }^{17}$ As Kahn puts it, proportionality review "is nothing more than the contemporary expression of reasonableness." Kahn, "Comparative Constitutionalism in a New Key," 2698.

${ }^{18}$ In modern memory, Star Chamber has become irredeemably associated with the later politically motivated abuses of its discretionary powers, particularly during the reign of Charles I, excesses that led to the abolition of Star Chamber in 1641.

${ }^{19}$ Johann P Sommerville, ed., King James VI and I: Political Writings (Cambridge and New York: Cambridge University Press, 1994), 216. 
Justice, where other Courts proceed only according to the strict rules of law." 20 He explained, "where the rigour of the Law in many cases will undo a Subject, there the Chancery tempers the Law with equity." ${ }^{21}$ Equitable courts were the locus for the expression of mercy and conscience; they were the institutional expression of a common sense in which justice was generated out of the interaction of the judgement of law and the political virtue of mercy. Writing in his 1528 treatise, Doctor and Student, Christopher St German explained the need for equity thusly:

sith the deeds and acts of men for which laws have been ordained happen in divers manners infinitely, it is not possible to make any general rule of the law but that it shall fail in some case. ... And therefore to follow the words of the law were in some case both against justice \& the commonwealth. Wherefore in some cases it is good and even necessary to leave the words of the law \& to follow that reason and justice requireth, \& to that intent equity is ordained; that is to say, to temper and mitigate the rigor of the law. ${ }^{22}$

Equity - the institutional expression of mercy - is the means by which those responsible for political and legal justice join the abstract principle of the legal rule with the messy, unpredictable, and unruly realities of lived experience.

This way of conceiving of justice was based in a political theology, one in which the justice that one would expect from God would be translated into the structures of state and kingship. In his speech in Star Chamber, King James expressed this link well when he explained that "Kings are properly Judges, and Judgment properly belongs to them from God: for Kings sit in the Throne of God, and thence all Judgment is derived." ${ }^{23}$ As the available theological resources of the time explained, mercy was a defining property of that divine justice. In his Summa Theologica, responding to an imagined interlocutor's objection that "mercy is a relaxation of justice" 24 unbecoming a just God, Aquinas explains that mercy is not best understood as a departure from justice: "mercy does not destroy justice, but in a sense is the fullness

\footnotetext{
${ }^{20}$ Sommerville, ed., King James VI and I, 214.

${ }^{21}$ Sommerville, ed., King James VI and I, 214.

${ }^{22}$ Christopher St. German, Doctor and Student (eds. Plucknett and Barton; London: Selden Society, 1974 [1528]), 97.

${ }^{23}$ Sommerville, ed., King James VI and I, 205.

${ }^{24}$ St. Thomas Aquinas, Summa Theologica (vol. 1; New York: Benzinger Brothers, 1947), 119.
} 
thereof." 25 And so one finds that in the $16^{\text {th }}$ and $17^{\text {th }}$ centuries, the higher justice found in God's mercy took institutional form in the equitable jurisdiction of the King. This is how mercy was sutured into the larger conception of justice in the history of the common law system. Equity was the means of ensuring "that the Gate of Mercie may bee opened in all Calamitie of Suit: to the end (where need shall bee) the Rigour of Law may bee amended, and the short measure thereof extended by the true consideration of Iustice and Equitie."26

The Book of Jonah feels distant from this institutional and juridical history. On the interpretation offered in this piece, however, both are responding to something similar in the phenomenology of justice, namely, the salience of mercy in the lived experience of justice. The success of the liberal rule of law has suppressed mercy in our political and legal vocabularies. And yet, though talk of mercy feels so foreign to the language in which we now formally discuss political and legal justice, the genealogical roots of the system and the mythical resources that have been the focus of this chapter still haunt our contemporary experience. Mercy appears not as wholly alien to us now but, rather, as uncanny. It is distant and yet somehow familiar. Freud described the uncanny as "in reality nothing new or alien, but something which is familiar and old-established in the mind and which has become alienated from it only through the process of repression."27 The uncanny is the "secretly familiar." 28 In our legal and political histories, as well as in our lived experience as reflected in our poetry, mercy is a secretly familiar dimension of justice. The uncanny conjures anxiety, wariness; it is, in some respects, frightening. For this reason, it is easier to respond to the uncanny with rejection rather than reckoning. And so it is with mercy in our modern conception of justice: it is unruly and ill fitted to a modern, secularized and rationalized legal and political culture and has therefore been exiled from - repressed in - authoritative discourse about the just. Yet there is no reason to think that the phenomenology of justice - that to which the myth of Jonah and the life of equity differently attended - has fundamentally changed. The shrouded persistence of sites for the exercise of discretion and conscience in our system of justice confirms what poetry suggests: that mercy is a real and essential part of the phenomenological

\footnotetext{
${ }^{25}$ Aquinas, Summa Theologica, 119.

${ }^{26}$ William Lambarde, Archeion: Or, a Discourse upon the High Courts of Justice in England (Cambridge, Mass.: Harvard University Press, 1957 [1635]), 45.

${ }^{27}$ Sigmund Freud, "The 'Uncanny'," in Art and Literature (ed. Dickson; vol. 14 of The Penguin Freud Library; London and New York: Penguin Books, 1985 (1919)) 339-76, 363-64.

${ }^{28}$ Freud, "The 'Uncanny,"' 368.
} 
architecture of justice, one that drops out of sight in modern legal and political reflection on justice. ${ }^{29}$

Such a misfit between modern modes of governance and what our history and cultural resources - our poetry and narratives - reflect about the lived challenges of doing justice should be of concern to legal and political theory. One might well ask what function this repression of mercy's role in justice serves. The myth at the heart of this chapter would suggest that, like Jonah, we find collective comfort in certainty and confidence in judgment untroubled by attention to the untidiness of everyday life. In matters of crime, fierceness in the movement from breach of a law to punishment enables swift passage past the knotted lines of responsibility for individual acts, past the moral complexity of both the criminal and the social world in which he acts, and past larger structures of injustice to which it is much more difficult to respond. In a liberal legal culture shored up by the assumptions and efficiencies essential to our modern economic order, repression of mercy's admonition to complicate is the easier path. A political or legal theorist might, then, wonder whether there is a link between this gap and the tendency to punitiveness and harshness, as well as the arid sense of social justice, so prevalent in contemporary politics and law. At minimum, refocusing on the relationship between mercy and justice, as the Book of Jonah still invites us to do, suggests a political and legal scholarship that spends as much time reflecting on the sources and nature of mercy as a political virtue, as it does on the demands of reason and the dictates of law alone.

\footnotetext{
${ }^{29}$ Benjamin L. Berger, "The Abiding Presence of Conscience: Criminal Justice Against the Law and the Modern Constitutional Imagination," University of Toronto Law Journal 61(2011): 579. For a rare and superb example of this kind of reflection, see Nussbaum, "Equity and Mercy."
} 


\section{Works Cited}

Aquinas, St. Thomas. Summa Theologica. Vol. 1. New York: Benzinger Brothers, 1947.

Ben Zvi, Ehud. Signs of Jonah: Reading and Rereading in Ancient Yehud. Journal for the Study of the Old Testament Supplement Series,367. London and New York: Sheffield Academic Press, 2003.

Berger, Benjamin L. "Picturing the Prophet: Focalization in the Book of Jonah." Studies in Religion 29. 1 (2000): 55-68.

--. "The Abiding Presence of Conscience: Criminal Justice Against the Law and the Modern Constitutional Imagination." University of Toronto Law Journal 61 (2011): 579.

Bolin, Thomas M. Freedom Beyond Forgiveness: The Book of Jonah Re-Examined. Sheffield: Sheffield Acadmic Press, 1997.

Craig, Kenneth M., Jr. A Poetics of Jonah: Art in the Service of Ideology. Columbia, SC: University of South Carolina Press, 1993.

Digeser, P.E. "Justice, Forgiveness, Mercy, and Forgetting: The Complex Meaning of Executive Pardoning." Capital University Law Review 31 (2003): 161.

Dilthey, Wilhelm. Gessammelte Schriften. Vol. VII. Stuttgart: B.G. Teubner, 1959.

Freud, Sigmund. "The 'Uncanny'," Pages 339-76 in Art and Literature. Edited by Albert Dickson. Vol. 14 of The Penguin Freud Library. London and New York: Penguin Books, 1985 [1919].

Hallo, William W. "Jonah and the Uses of Parody," Pages 285-291 in Thus Says the Lard: Essays on the Former and Latter Prophets in Honor of Robert R. Wilson. Edited by John J. Ahn and Stephen L. Cook. New York and London: T \& T Clark, 2009.

Kahn, Paul W. "Comparative Constitutionalism in a New Key." Michigan Law Review 101 (2003): 2677.

Kim, Hyun Chul Paul. "Jonah Read Intertextually." Journal of Biblical Literature 126.3 (2007): 497-528. 
Lambarde, William. Archeion: or, a Discourse upon the High Courts of Justice in England. Cambridge, MA.: Harvard University Press, 1957 [1635].

Latour, Bruno. The Making of Law: An Ethnography of the Conseil d'Etat. Cambridge, UK: Polity Press, 2010.

Nussbaum, Martha C. "Equity and Mercy." Philosophy \& Public Affairs 22.2 (1993): 83-125.

Palmer, Richard E. Hermeneutics: Interpretation Theory in Schleiermacher, Dilthey, Heidegger, and Gadamer. Evanston, IL: Northwestern University Press, 1969.

Perry, T. Anthony. The Honeymoon is Over: Jonah's Argument with God. Peabody, Mass.: Hendrickson Publishers, 2006.

Rawls, John. Justice as Fairness: A Restatement. Cambridge, MA: Belknap Press, 2001.

Sarat, Austin. Mercy on Trial: What it Means to Stop an Execution. Princeton: Princeton University Press, 2005.

Sarat, Austin and Nasser Hussain, eds. Forgiveness, Mercy, and Clemency. Stanford: Stanford University Press, 2007.

Sasson, Jack M. Jonah: A New Translation with Introduction, Commentary, and Interpretation. The Anchor Bible. New York and London: Doubleday, 1990.

Scholem, Gershom. "On Jonah and the Concept of Justice." Critical Inquiry 25.2 (1999): 353-61.

Simmonds, N. E. "Judgment and Mercy." Oxford Journal of Legal Studies 13.1 (1993): 52-68.

Sommerville, Johann P., ed. King James VI and I: Political Writings. Cambridge and New York: Cambridge University Press, 1994.

St. German, Christopher. Doctor and Student. Edited by T.F.T. Plucknett and J.L. Barton. London: Selden Society, 1974 [1528]. 